\title{
Assessment of cardiovascular findings in FMF related amyloid patients
}

\author{
Ailevi Akdeniz ateşine ikincil gelişen amiloidozda kardiyovasküler \\ bulguların değerlendirilmesi
}

\author{
Osman KÖSTEK ${ }^{1} \oplus$, Mümtaz TAKIR $^{1}$, Mustafa ÇALIŞKAN ${ }^{2} \odot$, Aytekin $^{\circ}$ OĞUZ $^{1} \odot$
}

\begin{abstract}
Aim: The aim of the study is to compare cardiovascular findings in amyloidosis developed secondary to familial Mediterranean fever (FMF), with those of patient, and healthy control groups.

Method: The study was performed on 32 secondary amyloid patients, 33 FMF patients and 65 healthy control individuals. Left ventricular functions were measured using two-dimensional, M-mode, conventional and tissue Doppler echocardiographic images. Aortic elasticity was analyzed using 2-D, M-mode echocardiographic images. Carotid-intima media thickness (CIMT) was measured using carotid artery B-mode ultrasonography.
\end{abstract}

Results: Age, sex and serum lipids were comparable among groups ( $p>0.05$ ). Aortic wall elasticity properties were similar between groups ( $p>0.05)$. Mitral annular E/A ratios were significantly lower in the amyloid group compared with controls $((p=0.004)$. CIMT was markedly higher in the amyloid group ( $p=0.001)$. In addition, CIMT values was higher in FMF patients than healthy controls $(p=0.03)$. Ejection fraction and left ventricular mass index were similar among groups ( $p>0.05$, for both).

Conclusion: These findings suggested that subclinical myocardial involvement may be present in patients who developed amyloidosis secondary to FMF: It is noted that CIMT values were higher in patients with secondary amyloidosis.

Keywords: FMF, secondary amyloidosis, CIMT, E/A ratio öz

Amaç: Ailevi Akdeniz ateşine (AAA) ikincil gelişen amiloidozda kardiyovasküler bulguların, amiloidoz gelişmeyen hasta ve sağIıklı kontrol gruplarıyla karşılaştırılması amaçlanmıştır.

Yöntem: Çalışmada, 33 sekonder amiloid hastası, 33 AAA hastası ile 65 sağlıklı kontrol olmak üzere 130 kişi yer aldı. Sol ventrikül fonksiyonlarının değerlendirilmesinde 2-boyutlu, M-mod, konvansiyonel ve doku doppler ekokardiyografi incelemeleri kullanıldı. Aortun elastik özelliklerinin incelenmesinde 2-boyutlu ve M-mod ekokardiyografi kullanıldı. Karotis intima-media kalınlığının ölçülmesinde karotis arter B-Mode ultrasonografi kullanıldı.

Bulgular: Hasta ve kontrol grubu yaş, cinsiyet, serum lipid düzeyleri açısından benzer özellikteydi $(p>0,05)$. Aortik elastik fonksiyon parametreleri hasta ve kontrol gurupları arasında benzerdi ( $p>0,05)$. Mitral annuler E/A oranı amiloid grubunda kontrollere göre anlamlı olarak daha düşüktü ( $p=0,004)$. Mitral annuler lateral Em/Am oranı amiloid grubunda benzer şekilde daha düşük iken ( $p=0,001)$, karotis intima-media kalınlığı amiloid grubunda belirgin derecede daha yüksek saptandı ( $p<0,001)$. AAA hastaların karotis intima-media kalınlığı sağlıklı kontrol grubuna göre daha yüksekti $(p=0,03)$. Ejeksiyon fraksiyonu ve sol ventrikül kitle indeksi gruplar arasında benzerdi ( $p>0,05$, her biri için).

Sonuç: Bu çalışmadaki bulgular, AAA'ya sekonder amiloid gelişen hastalarda subklinik bir miyokardiyal tutulumun olabileceğini düşündürmektedir. Sekonder amiloide bağlı karotis intima-media kalınlığının artışı dikkat çekmiştir.

Anahtar kelimeler: Ailevi Akdeniz ateşi, sekonder amiloid, karotis intima-media kalınlığı, E/A oranı

Received: 05.04 .2018

Accepted: 20.07.2018

${ }^{1}$ Istanbul Medeniyet University, Göztepe Training and Research Hospital, Department of Internal Medicine, İstanbul, Turkey

${ }^{2}$ Istanbul Medeniyet University, Göztepe Training and Research Hospital, Department of Cardiology, İstanbul, Turkey

Yazışma adresi: Osman Köstek, Istanbul Medeniyet University, Göztepe Training and Research Hospital, Department of Internal Medicine, İstanbul, Turkey e-mail: osmankostek@hotmail.com

Yazarların ORCiD bilgileri:

O.K. 0000-0002-1901-5603, M.Ç. 0000-0001-7417-4001, A.0. 0000-0002-2595-5167 


\section{Giriş}

Ailevi Akdeniz ateşi (AAA), ateşin periyodik serözit kliniği ile uyumlu karın, göğüs ve eklem ağrılarına eşlik ettiği, otozomal resesif geçişli bir inflamatuvar hastalıktır. AAA'nın komplikasyonları arasında en dikkat çekici ve prognozu etkileyen ise amiloidozistir $^{1}$. Amiloidozis genellikle renal hasara yol açmakta ve progrese olması ile son dönem renal yetmezliğe kadar yol açabilmektedir ${ }^{2,3}$. Sistemik amiloidoziste diğer taraftan sıklıkla karaciğer, dalak ve adrenallerin de tutulmasına rağmen, nadiren kalp, sinir sistemi, tiroid, akciğer, testis, gastrointestinal ve kas-iskelet sistemi de tutulabilir ${ }^{4-7}$.

Kardiyak amiloidoz ise değişik insan plazma proteinlerinden türetilmiş amiloid proteininin ventrikül duvarları ve septumda ekstraselüler olarak birikmesi sonucu oluşmakta ve ilerleyen dönemde ileti bozuklukları, restriktif kardiyomiyopati ile düşük atımlı kalp yetersizliğine yol açmaktadır ${ }^{5,6}$. Yapılan çalışmalarda primer amiloidozun miyokardı daha fazla tuttuğu bildirilse de benzer ekokardiyografik değişikliklerin AAA'lı grupta saptanması, bu hastaların takibinde transtorasik ekokardiyografinin belirleyici ve yol gösterici olduğunu düşündürmektedir ${ }^{6,7}$. Bu çalışmanın amacı, ailevi Akdeniz ateşine ikincil gelişen amiloidozda kardiyovasküler bulguların, amiloidoz gelişmeyen hasta ve sağlıklı kontrol gruplarıyla karşılaştırılmasıdır.

\section{GEREÇ ve YÖNTEM}

Çalışma retrospektif eşleştirilmiş vaka-kontrol çaIışması olup, hastanemizin Kardiyoloji ve Nefroloji polikliniklerine başvuran 65 hasta ile yaş ve cinsiyet bakımından benzer 65 sağlıklı kontrol grubu ile çaIışmaya dahil edilmiştir. Tell-Hashomer kriterlerine göre AAA tanılar konmuş hastalar ise hastanemizin iç hastalıkları, romatoloji, nefroloji ve kardiyoloji polikliniklerinden takip ediliyordu. Çalışmamıza amiloidoz gelişmiş AAA hastalarından (19'u erkek, 13'ü kadın) 32 hasta ve amiloidoz gelişmemiş AAA hastalarından 33 hasta (16 erkek, 17 kadın) olmak üzere toplam 65 kişi hasta grubunu oluşturmaktaydı. Çalışmamıza (35 erkek, 30 kadın) 65 sağlıklı kontrol grubu olmak üzere toplamda 130 kişi dahil edilmiştir. Çalışma için hastanemizin etik komisyonu (Tarih: 2 Aralık 2014, karar No. 2014/0177) onayı alındı.

\section{Çalışmaya Alınma Kriterleri:}

1. On sekiz yaş ve üstü erişkin bireyler

2. Ailevi Akdeniz ateşi (AAA) tanısı olan akut atakta olmayan hastalar

3. AAA'ya sekonder amiloidozisi olan hastalar

4. Kontrol grubunu oluşturan sağlıklı bireyler

\section{Dışlama Kriterleri:}

1. On sekiz yaş altında yer alan bireyler

2. Aritmisi olan hastalar

3. Edinsel veya konjenital kalp hastalığı olanlar

4. Perikardit hastaları

5. AAA'ya bağlı akut atak durumu olan hastalar

6. Primer amiloidozis tanılı hastalar,

7. Kontrolsüz hipertansiyon veya hiperglisemi veya bunlara bağlı organ hasarı olan hastalar

8. Sistemik hastalıklara bağlı nefrotik veya klinik anlamlı derecede proteinurisi olan hastalar.

AAA ve Sekonder Amiloidoz Tanısı: Hasta takip raporlarında AAA tanılı hastaların tümü kolşisin tedavisi ile takip ediliyordu. Sekonder amilod hasta grubunda ise çoğu renal biopsi sonrası amiloid tanısı almış, 4 hasta ise renal biopsi öyküsü olmadan AAA tanısı ile eşlik eden nefrotik düzeyde proteinürisi ile beraber nefrotiksendrom kliniği olması üzerine amiloidoz kabul edildi.

Çalışma Tasarımı: Hasta ve kontrol grubunaait anamnez, fizik muayene, ekokardiyografik ve laboratuvar verileri hasta kayıt raporlarından elde edilmiştir.

Laboratuvar Parametreleri: C-reaktif protein, sedimentasyon, hemoglobin; açlık plazma kan şekeri, HDL, $\mathrm{LDL}$, total kolesterol, trigliserid değerleri kaydedildi.

Ekokardiyografik Değerler: Hastalar kardiyoloji poliklinik şartlarında 1 kardiyoloji uzmanı tarafından değerlendirildi. Sol ventrikül fonksiyonlarının değerlendirilmesinde 2-boyutlu, M-mod ve standart Doppler ekokardiyografi incelemeleri kullanıldı. Aortun elastik 
özelliklerinin incelenmesinde 2-boyutlu ve M-mod ekokardiyografi kullanıldı. Ortalama duvar kalınlıkları, sol atrium genişliği, transmitral akım paternleri [E/A oranı], bunun azalma zamanı (AZ) ve ejeksiyon fraksiyonu (EF) ile karotis-intima media kalınlıkları ölçümleri kaydedildi. Karotis Arter B-Mode ultrasonografi incelemeleri, ATL 3500 marka ultrasonografi cihazı ile 5-12 $\mathrm{MHz}$ lineer array transduser ile yapıldı. Bütün ultrasonografi incelemeri aynı operatör tarafından yapıldı. Sol ventriküler diyastolik disfonksiyon konvansiyonel dopplerde mitral $E / A<1$ ise doku dopplerde ise lateral $\mathrm{Em} / \mathrm{Am}<1$ olarak değerlendirildi.

Sol ventrikül kitle indeksi ise Devereux formulü (SVKi) $=[0,8 \times 1,04 \times[$ (interventriküler septum kalınlığı + arka duvar kalınlığı+interventriküler septum kalınlığı) 3 - sol ventrikül diyastol sonu çapı3] + 0,6 ]/Vücut yüzey alanı $\left(1,7 \mathrm{~m}^{2}\right)$ ile hesaplandı 8 .

Aort elastisitesini değerlendirmek için, aortik "strain", beta indeksi, "distensibilite" parametreleri incelendi. Bu parametrelerin hesaplanmasında aşağıdaki formüller kullanıldı?:

Aortik Strain (\%)= (sistolik çap-diyastolik çap) x 100 / diyastolik çap

Beta İndeksi= In (sistolik basınç/diyastolik basınç) / aortik strain

Distensibilite $\left(\mathrm{cm}^{2} / \mathrm{dyn}-1\right)=2$ (aortik strain) / (sistolik basınç-diyastolik basınç)
İstatiksel Analiz: Kategorik verilerin analizi ki-kare testi ile yapılacaktır. Sayısal verilerin analizinde Kolmogorov-Smirnov Testi ile normal dağılıp dağılmadığı incelendi. Normal dağılım gösteren veriler arasında tek yönlü varyans analizi (ANOVA) ve değişkenler arasındaki farkı belirlemek için de post-hoc Tukey testi uygulandı. Normal dağılım göstermeyen veriler ise non-parametrik test karşılığı olan Kruskal-Wallis testi ile değerlendirildi. İkili gruplar arasında sayısal veriler ise normal dağılım gösteriyorsa student $t$ testi, normal dağılım göstermiyorsa non-parametrik karşılığı olan Mann Whitney $U$ testi ile değerlendirildi. $p<0,05$ değeri istatiksel olarak anlamlı kabul edildi.

\section{BULGULAR}

Amiloid gelişen hastaların yaş ortalaması $42 \pm 12$, AAA hastalarında ise $37 \pm 12$ iken, kontrol grubunda $39 \pm 8$ saptandı (Tablo 1) Amiloid gelişen hastalarda erkek/ kadın oranı 35/30, AAA hastalarında $16 / 17$ iken, kontrol grubunda ise $19 / 14$ saptandı $(p=0,68)$. Vücut kitle indeksi hasta ve kontrol grupları arasında farklılık göstermekteydi (amiloid vs kontrol $p<0,001$, amiloid vs AAA $p<0,001)$. Amiloid gelişen hastaların vücut kitle indeksi diğer gruplardan göre belirgin şekilde daha düşüktü. AAA hastaları ile kontrol grubunun vücut kitle indeksleri benzerdi (AAA vs kontrol $p=0,49$ ). Hastaların sistolik ve diyastolik kan basıncı değerleri gruplar arasında benzerdi ( $p=0,10$ ve $p=0,56$, sırasıyla).

Sedimentasyon hızı AAA hastalarında daha yüksek

Tablo 1. Hastalara ait demografik ve klinik özellikler.

\begin{tabular}{|c|c|c|c|c|c|}
\hline & $\begin{array}{l}\text { Tümü } \\
(n=130)\end{array}$ & $\begin{array}{l}\text { Kontrol } \\
(n=65)\end{array}$ & $\begin{array}{l}\text { AAA } \\
(n=33)\end{array}$ & $\begin{array}{l}\text { Amiloid } \\
(n=32)\end{array}$ & $\mathbf{p}$ \\
\hline Yaş (yıl) & $39 \pm 10$ & $39 \pm 8$ & $37 \pm 12$ & $42 \pm 12$ & 0,45 \\
\hline Erkek/Kadın (n/n) & $70 / 60$ & $35 / 30$ & $16 / 17$ & $19 / 13$ & 0,68 \\
\hline \multicolumn{6}{|l|}{ VKi $\left(\mathrm{kg} / \mathrm{m}^{2}\right)$} \\
\hline Ortanca & 25,9 & 27,4 & 25,6 & 21,3 & \multirow[t]{2}{*}{$<0,001$} \\
\hline Çeyrekler arası aralık & $21,4-28,1$ & $23,9-28,9$ & $22,7-28,3$ & $20,7-22,8$ & \\
\hline \multicolumn{6}{|l|}{ Sistolik KB (mmHg) } \\
\hline Ortanca & 120 & 120 & 120 & 129 & \multirow[t]{2}{*}{0,10} \\
\hline Çeyrekler arası aralık & $110-135$ & $110-130$ & $110-130$ & $110-147$ & \\
\hline \multicolumn{6}{|l|}{ Diyastolik KB (mmHg) } \\
\hline Ortanca & 80 & 80 & 80 & 80 & \multirow[t]{2}{*}{0,56} \\
\hline Çeyrekler arası aralık & $70-80$ & $70-80$ & $70-80$ & $70-90$ & \\
\hline
\end{tabular}


saptanırken, AAA hasta grubu ile kontrol grupları arasında sedimentasyon hızı istatiksel açıdan farklıydı $(p=<0,05)$, diğer taraftan sekonder amiloid gelişen hastalarda sedimentasyon hızı kontrol ve AAA hastalarındakine göre istatiksel farklılık göstermemekteydi $(p=0,15$ ve $p=0,53$, sırasıyla). Açlık plazma kan şekeri, CRP, total kolesterol, HDL ve LDL kolesterol ile trigliserid değerleri hasta ve kontrol grupları arasında benzerdi ( $p>005$, her biri için; Tablo 2 ).

Kalp boyutlarına ait ölçümler Tablo 3'te gösterilmiştir. Sol atrium, interventriküler septum, sol ventrikül sistol ve diyastol çapı ölçümleri hasta ve kontrol gruplarında benzer boyutlarda idi ( $p=0,43, p=0,34, p=0,08$ ve $p=0,09$; sırasıyla). Arka duvar ölçümleri amiloidi olan hastalarda (ortanca değer $=1 \mathrm{~cm}$, çeyrekler arası mesafe =0,9-1,1 cm), AAA (ortanca değer $=0,9 \mathrm{~cm}$, çeyrekler arası mesafe $=0,9-0,9 \mathrm{~cm}$, amiloid vs AAA grupları için $p<0,001$ ) ve kontrol grubuna (ortanca değer $=0,9 \mathrm{~cm}$, çeyrekler arası mesafe $=0,9-1,0 \mathrm{~cm}$, amiloid ve kontrol grupları için $p<0,001)$ göre yüksek bulunmuştur $(p<0,01)$, AAA hastaların arka duvar ölçümleri kontrol grubu ile benzer idi $(p=0,92)$. Ejeksiyon fraksiyonu tüm populasyonda minimum $\% 50$, maksimum \%77 olarak ölçüldü. Amiloid grubunda ejeksiyon fraksiyonu $\% 62,7 \pm 5,3$, AAA grubunda $65,4 \pm 46$, kontrol grubunda ise $66,8 \pm 2,6$ idi (Tablo 3 ).

Mitral kan akım hızının değerlendirilmesinde konvansiyonel ekokardiyografide $\mathrm{E}$ dalgası kontrol grubunda daha yüksek, amiloid grubunda ise düşük saptanmasına rağmen, gruplar arasında istatiksel derecede anlamlı farklılık saptanmadı $(p=0,31)$. Mitral $A$ dalgası ise amiloid grubunda (ortanca $=68 \mathrm{~cm} / \mathrm{s}$, çeyrekler arası mesafe $=59-77 \mathrm{~cm} / \mathrm{s}$ ) kontrol (ortanca $=60 \mathrm{~cm} / \mathrm{s}$, çeyrekler arası mesafe $=51-76 \mathrm{~cm} / \mathrm{s}$ ) ve AAA grubuna (ortanca $=66 \mathrm{~cm} / \mathrm{s}$, çeyrekler arası mesafe $=59-78$ $\mathrm{cm} / \mathrm{s}$ ) göre yüksek saptandı. Kontrol grubu ile AAA (kontrol vs AAA $p=0,02$ ) ve amiloid (kontrol vs amiloid $p<0,05)$ grupları arasında istatiksel farklılık bulunurken, AAA ve amiloid grupları arasında anlamlı farklılık yoktu $(p=0,74)$.

Mitral E/A oranı benzer şekilde kontrol ile AAA grubu

Tablo 2. Gruplar arası laboratuvar parametrelerinin dağılımı.

\begin{tabular}{|c|c|c|c|c|c|}
\hline & $\begin{array}{l}\text { Tümü } \\
(n=130)\end{array}$ & $\begin{array}{l}\text { Kontrol } \\
(n=65)\end{array}$ & $\begin{array}{l}\text { AAA } \\
(n=33)\end{array}$ & $\begin{array}{l}\text { Amiloid } \\
(n=32)\end{array}$ & $\mathbf{p}$ \\
\hline \multicolumn{6}{|l|}{$\mathrm{CRP}(\mathrm{mg} / \mathrm{dL})$} \\
\hline Ortanca & 1,3 & 1,3 & 1,7 & 0,3 & \multirow[t]{2}{*}{0,06} \\
\hline Çeyrekler arası aralık & $0,7-2,5$ & $0,8-2,5$ & $1,2-4,3$ & $0,0-0,78$ & \\
\hline \multicolumn{6}{|l|}{ Sedimentasyon $(\mathrm{mm} / \mathrm{h})$} \\
\hline Ortanca & 19 & 11 & 23 & 14 & \multirow[t]{2}{*}{$<0,01$} \\
\hline Çeyrekler arası aralık & $12-30$ & $8-18$ & $15-33$ & $14-26$ & \\
\hline \multicolumn{6}{|l|}{ Açlık kan şekeri (mg/dL) } \\
\hline Ortanca & 92 & 90 & 92 & 98 & \multirow[t]{2}{*}{0,06} \\
\hline Çeyrekler arası aralık & $87-97$ & $87-96$ & $88-97$ & $95-110$ & \\
\hline \multicolumn{6}{|l|}{ Hemoglobin $(\mathrm{g} / \mathrm{dL})$} \\
\hline Ortanca & 14,2 & 14,3 & 14,2 & 13,5 & \multirow[t]{2}{*}{0,47} \\
\hline Çeyrekler arası aralık & $13,1-15,3$ & $13,3-15,4$ & $12,9-15,4$ & $12,5-14,9$ & \\
\hline \multicolumn{6}{|l|}{ Total kolesterol (mg/dL) } \\
\hline Ortanca & 180 & 180 & 176 & 180 & \multirow[t]{2}{*}{0,64} \\
\hline Çeyrekler arası aralık & $160-201$ & $160-205$ & $156-210$ & $174-190$ & \\
\hline \multicolumn{6}{|l|}{ HDL kolesterol (mg/dL) } \\
\hline Ortanca & 40 & 41 & 42 & 39 & \multirow[t]{2}{*}{0,21} \\
\hline Çeyrekler arası aralık & $35-49$ & $35-51$ & $38-51$ & $33-46$ & \\
\hline \multicolumn{6}{|l|}{ LDL kolesterol (mg/dL) } \\
\hline Ortanca & 112 & 110 & 110 & 125 & \multirow[t]{2}{*}{0,08} \\
\hline Çeyrekler arası aralık & $91-131$ & $89-131$ & $87-126$ & $110-134$ & \\
\hline \multicolumn{6}{|l|}{ Trigliserid (mg/dL) } \\
\hline Ortanca & 137 & 125 & 121 & 140 & \multirow[t]{2}{*}{0,39} \\
\hline Çeyrekler arası aralık & $96-190$ & 93-199 & 70-199 & $134-170$ & \\
\hline
\end{tabular}


Tablo 3. Gruplar arası laboratuvar parametrelerinin dağılımı.

\begin{tabular}{|c|c|c|c|c|c|}
\hline & $\begin{array}{l}\text { Tümü } \\
(n=130)\end{array}$ & $\begin{array}{l}\text { Kontrol } \\
(n=65)\end{array}$ & $\begin{array}{l}\text { AAA } \\
(n=33)\end{array}$ & $\begin{array}{l}\text { Amiloid } \\
(n=32)\end{array}$ & $\mathbf{p}$ \\
\hline \multicolumn{6}{|l|}{ Sol atrium çapı, (cm) } \\
\hline Ortanca & 3,1 & 3,0 & 3,2 & & \multirow[t]{2}{*}{0,43} \\
\hline Çeyrekler arası aralık & $2,9-3,3$ & $2,8-3,3$ & $3,0-3,3$ & $2,9-3,3$ & \\
\hline \multicolumn{6}{|c|}{ Sol ventrikül sistol çap, (cm) } \\
\hline Ortanca & 2,9 & 3,0 & 2,8 & 3,1 & \multirow[t]{2}{*}{0,08} \\
\hline Çeyrekler arası aralık & $2,7-3,1$ & $2,7-3,0$ & $2,7-3,1$ & $2,8-3,2$ & \\
\hline \multicolumn{6}{|c|}{ Sol ventrikül diyastol çap, (cm) } \\
\hline Ortanca & 4,6 & 4,7 & 4,6 & 4,7 & \multirow[t]{2}{*}{0,09} \\
\hline Çeyrekler arası aralık & $4,3-4,8$ & $4,3-4,8$ & $4,2-4,7$ & $4,6-5,0$ & \\
\hline \multicolumn{6}{|c|}{ İnterventriküler septum, (cm) } \\
\hline Ortanca & 0,9 & 0,9 & 0,9 & 1,0 & \multirow[t]{2}{*}{0,34} \\
\hline Çeyrekler arası aralık & $0,8-1,0$ & $0,8-1,0$ & $0,9-1,0$ & $0,8-1,1$ & \\
\hline \multicolumn{6}{|l|}{ Arka Duvar $(\mathrm{cm})$} \\
\hline Ortanca & 0,9 & 0,9 & 0,9 & 1,0 & \multirow{2}{*}{$<0,001$} \\
\hline Çeyrekler arası aralık & $0,8-1,0$ & $0,8-1,0$ & $0,9-0,9$ & $0,9-1,1$ & \\
\hline \multicolumn{6}{|l|}{ Ejeksiyon fraksiyonu (\%) } \\
\hline Ort, $\pm S D$ & $65,4 \pm 4,2$ & $66,8 \pm 2,6$ & $65,4 \pm 4,6$ & $62,7 \pm 5,3$ & $<0,001$ \\
\hline \multicolumn{6}{|l|}{ Mitral Akım } \\
\hline \multicolumn{6}{|l|}{ E pik hızı, (cm/s) } \\
\hline Ortanca & 76 & 78 & 74 & 70 & 0,31 \\
\hline Çeyrekler arası aralık & $66-88$ & $68-86$ & $62-89$ & $65-83$ & \\
\hline A pik hızı, $(\mathrm{cm} / \mathrm{s})$ & & & & & \\
\hline Ortanca & 64 & 60 & 66 & 68 & $<0,05$ \\
\hline Çeyrekler arası aralık & $57-76$ & $53-71$ & $59-78$ & $59-77$ & \\
\hline E/A oranı & & & & & \\
\hline Ortanca & 1,2 & 1,3 & 1,1 & 1,1 & $<0,01$ \\
\hline Çeyrekler arası aralık & $0,9-1,3$ & $1,1-1,4$ & $0,9-1,3$ & $0,8-1,3$ & \\
\hline$E / A<1, n(\%)$ & $33(25,4)$ & $9(13,8)$ & $11(33,3)$ & $13(40,6)$ & $<0,01$ \\
\hline E dalgası DT (ms) & & & & & \\
\hline Ortanca & 193 & 189 & 202 & 202 & $<0,05$ \\
\hline Çeyrekler arası aralık & $178-204$ & $177-200$ & $182-221$ & $179-221$ & \\
\hline Lat Em pik hızı, (cm/s) & & & & & \\
\hline Ortanca & 19 & 20 & 20 & 18 & $<0,05$ \\
\hline Çeyrekler arası aralık & $16-22$ & $17-22$ & $16-23$ & $14-19$ & \\
\hline Lat Am pik hızı, (cm/s) & & & & & \\
\hline Ortanca & 15 & 14 & 16 & 20 & $<0,001$ \\
\hline Çeyrekler arası aralık & $13-19$ & $12-15$ & $14-18$ & $17-22$ & \\
\hline Lat Em/Am oranı & & & & & \\
\hline Ortanca & 1,2 & 1,4 & 1,3 & 0,9 & $<0,001$ \\
\hline Çeyrekler arası aralık & $0,9-1,6$ & $1,1-1,7$ & $1,0-1,8$ & $0,8-1,0$ & \\
\hline Lat Em/Am<1, n (\%) & $32(24,6)$ & $7(10,7)$ & $8(24,2)$ & $17(53,1)$ & $<0,001$ \\
\hline Aort Elastisitesi & & & & & \\
\hline AOS, $(\mathrm{cm})$ & & & & & \\
\hline Ortanca & 3,2 & 3,2 & 3,2 & 3,2 & 0,08 \\
\hline Çeyrekler arası aralık & $2,8-3,5$ & $2,6-3,5$ & $3,0-3,6$ & $3,0-3,5$ & \\
\hline$A O D,(c m)$ & & & & & \\
\hline Ortanca & & 2,8 & & & 0,21 \\
\hline Çeyrekler arası aralık & $2,5-3,4$ & $2,3-3,4$ & $2,8-3,4$ & $2,8-3,3$ & \\
\hline Aortik strain, (\%) & & & & & \\
\hline Ortanca & 7,4 & 8,3 & 6,7 & 6,9 & 0,61 \\
\hline Çeyrekler arası aralık & $3,7-9,5$ & $3,7-9,5$ & $3,6-9,9$ & $5,6-10,3$ & \\
\hline Beta indeks & & & & & \\
\hline Ortanca & 5,8 & 5,2 & 7,1 & 5,8 & 0,24 \\
\hline Çeyrekler arası aralık & $4,1-9,6$ & $3,9-7,5$ & $4,4-11,8$ & $4,6-9,2$ & \\
\hline Aortik distensibilite $\left(\mathrm{cm}^{2}\right.$ & & & & & \\
\hline Ortanca & 34 & 38 & 28 & 33 & 0,40 \\
\hline Çeyrekler arası aralık & $19-48$ & $20-52$ & $17-46$ & $19-45$ & \\
\hline Karotis intima-media kal & & & & & \\
\hline Ortanca & 0,60 & 0,50 & 0,60 & 0,70 & $<0,001$ \\
\hline Çeyrekler arası aralık & $0,50-0,70$ & $0,45-0,60$ & $0,50-0,70$ & $0,60-0,80$ & \\
\hline Sol ventrikül kitle indeks & & & & & \\
\hline Ort, \pm SD & $79,9 \pm 16,5$ & $82,6 \pm 17,8$ & $75,1 \pm 15,2$ & $785 \pm 8,1$ & 0,09 \\
\hline Sol ventrikül FS (\%) & & & & & \\
\hline Ortanca & 37,1 & 37,2 & 36,5 & 36,6 & \\
\hline Çeyrekler arası aralık & $34,6-39,1$ & $35,5-38,7$ & $34,1-40,4$ & $34,1-38,9$ & 0,91 \\
\hline
\end{tabular}


$(p<0,05)$ ve kontrol ile amiloid grubu $(p<0,01)$ arasında istatiksel açıdan farklııı içerirken, AAA ile amiloid grubu arasında anlamlı ilişki saptanmadı $(p=0,58$, Figür 1). Mitral $E / A<1$ (sol ventrikül diyastolik disfonksiyon) olanların oranı tüm grupta $\% 25,4$ idi (Tablo 3 ). Bu oran amiloid hasta grubunun $\% 40,6$ 'da, AAA grubunun $\% 33,3$ 'ünde, kontrol grubunun ise $\% 13,8^{\prime}$ inde saptandı ( $p<0,01$, Tablo 3). Mitral E dalgası deselarasyon zamanı (AZ) gruplar arasında farklılık içermekteydi $(p<0,05)$. Ancak bu süre yalnızca kontrol ve AAA grubu arasında istatiksel olarak anlamlı farklılık içerirken $(p<0,01)$, amiloid ve kontrol grubu arasında ise benzerdi $(p=0,11)$. Amiloid ve AAA grupları arasında deselarasyon zamanları istatiksel açıdan anlamlı farklılık yoktu ( $p=0,89$; Tablo 3$)$.

Mitral kapak annuler bölgesel akım hızının doku doppler incelemesinde, lateral Em dalgası kontrol grubunda daha yüksek, amiloid grubunda ise düşük saptandı ( $p<0,05 ;$ Tablo 3). Gruplar arasında istatiksel derecede anlamlılık amiloid ile kontrol $(p<0,01)$ ve amiloid ile AAA $(p<0,05)$ arasında mevcut iken kontrol ile AAA arasında istatiksel farklılık yoktu $(p=0,57)$. Lateral Am dalgası amiloid grubu ile kontrol grupları $(p<0.001)$ arasında, amiloid ile AAA grupları $(p<0,01)$ arasında ve kontrol ile AAA grupları $(p<0.01)$ arasında istatiksel anlamlılık içermekteydi (Tablo 3).

Lateral Em/Am oranı kontrol ile amiloid grubu $(p<0,001)$ ve AAA ile amiloid grubu $(p<0,01)$ arasında istatiksel açıdan farklılık içerirken, AAA ile kontrol grubu arasında anlamlı ilişki saptanmadı ( $p=0,35$, Figür 2, Tablo 3). Lateral Em/Am<1 olanların oranı tüm grupta \%24,6 idi (Tablo 4.3). Bu oran amiloid hasta grubunun $\% 53,1$ 'de, AAA grubunun $\% 24,2$ 'sinde, kontrol grubunun ise $\% 10,7$ 'sinde saptandı $(p<0,001$, Tablo 3).

Hastaların aort elastisitesi açısından aort sistolik çap, aort diyastolik çapı değeri gruplar arasında benzerdi ( $p=0,08, p=0,21$, sirasıly). Aortik strain, $ß$-indeks ve aortik distensibilite değerleri gruplar arasında farklı olmadığını belirledik ( $p=0,61, p=0,24$ ve $p=0,40$, sırasıyla; Tablo 3). Sol ventrikül kitle indeksi ve fraksiyonel kısalma oranları gruplar arasında istatiksel açın-

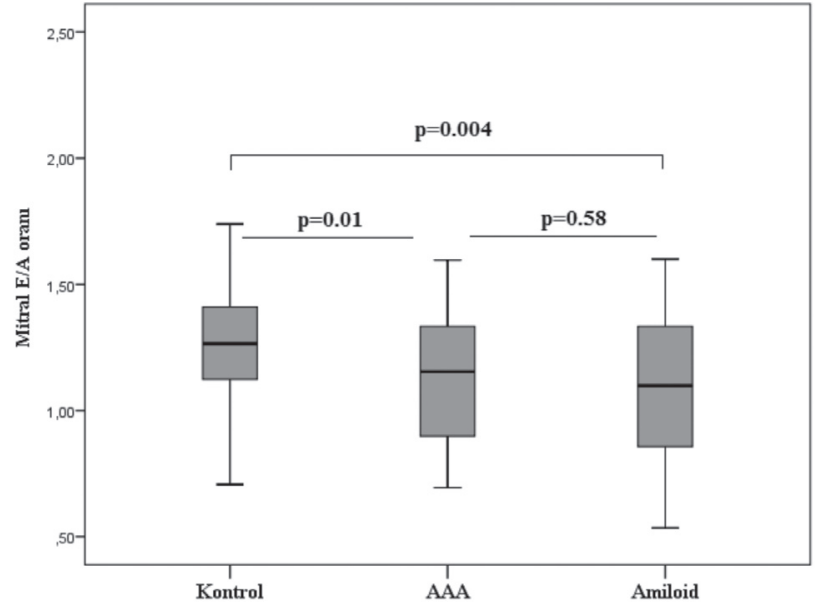

Figür 1. Mitral E/A oranının gruplar arasında dağılımı.

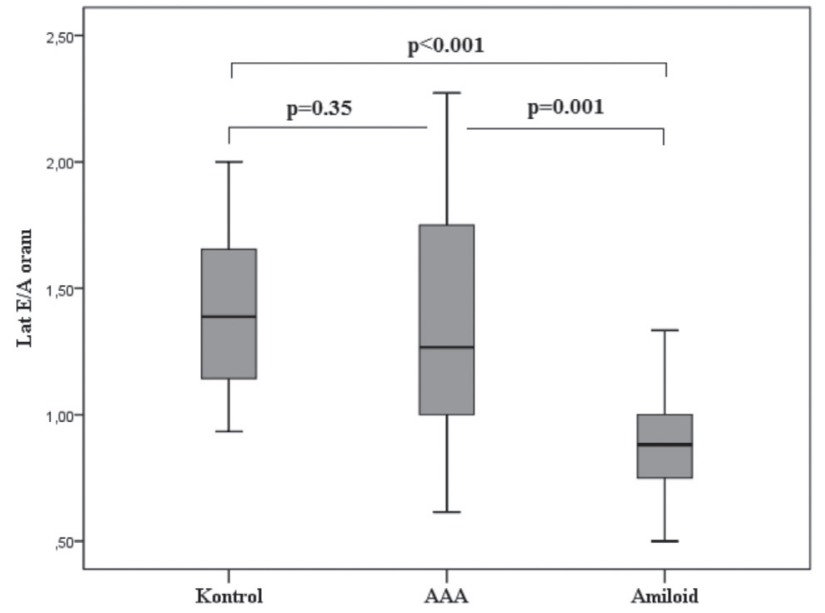

Figür 2. Lat Em/Am oranının gruplar arasında dağılımı.

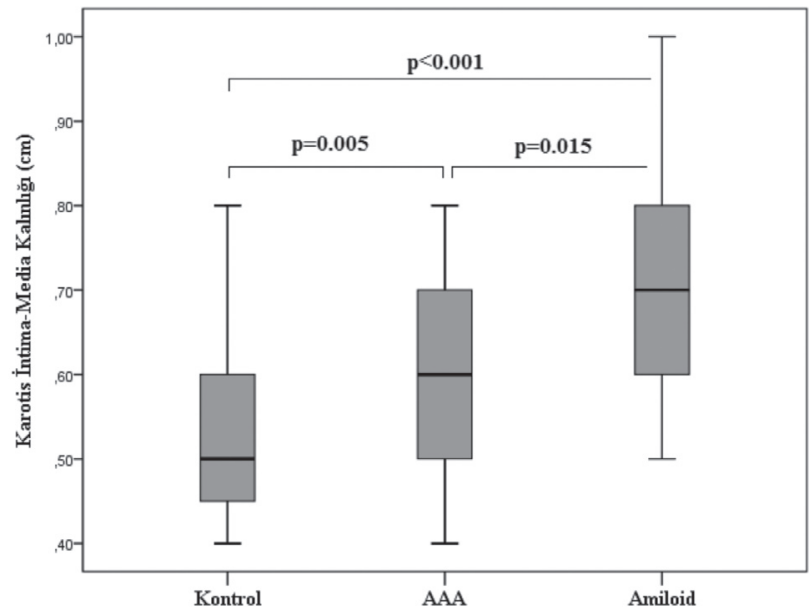

Figür 3. Karotis intima-media kalınlığının gruplar arasında dağılımı. 
dan benzerdi ( $p=0,09$ ve $p=0,91$, sırasıyla, Tablo 3).

Karotis arter intima-media kalınlık değerleri Tablo 3'te gösterilmiştir. Amiloid hastalarında karotis intima-media kalınlığı, AAA hasta ve kontrol gruplarından istatiksel açıdan anlamlı derecede daha yüksekti ( $p<0,05$ ve $p<0,001$, sırasıyla). AAA hasta grubunun karotis intima-media kalınlığı kontrol grubundan da fazla idi ( $p<0,05$, Figür 3 , Tablo 3 ).

\section{TARTIŞMA}

Kardiyak amiloidoz; kalp yetersizliği, restriktif kardiyomiyopati, aritmi, konstruktif perikardit ile uyumlu klinik prezentasyon gösterebilir ${ }^{10}$. Tanı konması güç olan kardiyak amiloidozun kalp yetersizliği, perikard konstriksiyonu, aritmi ve ani ölüm ile başvuran hastalarda etiyolojiyi saptamada araştırılması gereken bir hastalık olduğunu düşünmekteyiz. Kalp yetersizliği semptomları ile karşımıza çıkan hastaların yaklaşık üçte birinde sol ventrikülün sistolik fonksiyonları normal bulunmakta ve diyastolik disfonksiyon tanısına varılmaktadır ${ }^{11}$. Çalışmamızda, AAA olgularına sekonder gelişen amiloidozlu hastaların sağlıklı kontrol ve AAA olup amiloidoz gelişmeyen hasta gruplarına göre sol ventrikül sistolik fonksiyonlarının normal, diyastolik disfonksiyon sıklığının ise fazla olduğunu saptadık.

Amiloid, AAA ve sağlıklı kontrol gruplarının vücut kitle indekslerine ait literatürde kısıtlı veri mevcuttur. Güven ve ark. ${ }^{4}$ AAA'ya sekonder gelişen amiloid hastalarının vücut kitle indeksinin, AAA hastaları ile normal değerler arasında olduklarını ve istatiksel açıdan farklılık göstermediklerini belirlemişlerdir. ÇaIışmamızda ise vücut kitle indeksi amiloid grubunda (ortanca değeri $21,3 \mathrm{~kg} / \mathrm{m}^{2}$ ) sağ ıklı kontrol (ortanca değeri $27,4 \mathrm{~kg} / \mathrm{m}^{2}$ ) ve AAA grubuna (ortanca değeri $\left.25,6 \mathrm{~kg} / \mathrm{m}^{2}\right)$ göre belirgin olarak düşük saptanmış$\operatorname{tır}(p<0,001)$. AAA grubunun vücut kitle indeksi ile sağlıklı kontrol grubu benzerdi ( $p>0,05)$. Vücut kitle indeksi amiloid grubunda normal değerler arasında iken, sağlıklı kontrol ve AAA hastalarının hafif şişman oldukları görüldü.
Amiloidozu olmayan AAA'lı olguların hiçbiri test sırasında atak döneminde değildi. CRP ve sedimentasyon hızıdeğerleri AAA hastalarında daha yüksek saptanmasına rağmen normal sınırlardaydı. Literatürde HDL'nin major proteini olan apolipoprotein A-1 ile ailevi amiloid mutasyon genleri arasında benzerlikler saptanmış ve diğer bir çalışmada ise serebral amiloid gelişen olgularda yüksek LDL ve düşük HDL kolesterol değerlerinin risk faktörü olduğu gösterilmiştir ${ }^{12,13}$. Sekonder amiloid hastalarında benzer çalışmalara rastlanılamamıştır. Çalışmamızda, total kolesterol, LDL ve HDL kolesterol ve trigliserid değerleri gruplar arasında benzerdi.

Amiloid proteininin birikmesine bağlı ventriküler esnekliğin azalması ile gelişen diyastolik doluş bozukluğu doppler ekokardiyografi ile belirlenebilmekte, ayrıca amiloid infiltrasyonun derecesine göre farklı akım örnekleri elde edilmektedir. Kardiyak amiloidozun erken döneminde relaksasyon bozukluğu ön planda olup, mitral akım örneğinde erken diyastolik akım velositesinin azaldığı geç diyastolik akım velositesinin arttığı, izovolumetrik relaksasyon süresinin uzadığı saptanmıştır. Diyastolik disfonksiyonun farkIı doluş paternleri belirtilmiştir. Normal patern, sol ventrikül kompliyansı, relaksasyon hızı ve dolma basınçları normaldir. Geçikmiş relaksasyon, sol ventrikül relaksasyon hızı azalmış olmasına rağmen, dolma basınçları ve kompliyansı normaldir. Psödonormalizasyon relaksasyondaki uzama ile beraber kompliyansta azalma, böylelikle sol atrium basıncında da yükselme mevcuttur. Restriktif patern esneyebilme ve relaksasyon özelliklerinin kaybolduğu safha olup, artmış miyokard sertliği belirgindir: $E / A>2 \quad A Z<150$ IVRZ<60 msn olmaktadır ${ }^{14,15}$. Çalışmamızda, benzer şekilde sol ventrikül erken diyastolik akım velositelerinin düşüklüğü ile geç diyastolik akım velositelerinin artışı, sekonder amiloid grubunda daha belirgindi. DT amiloid ve AAA grubunda kontrol grubuna göre daha fazla uzamış olduğu görüldü. Ancak bu süre yalnızca kontrol ve AAA grubu arasında istatiksel olarak anlamlı farklılık içerirken $(p<0,01)$, amiloid ve kontrol grubu arasında ise benzerdi $(p=0,11)$. Doku doppler ekokardiyografi diyastolik disfonksiyonu göstermede daha değerlidir ${ }^{16}$. Konvansiyonel ekokardiyografik in- 
celemede mitral E/A oranı 1'in altında olan hastaların $\% 40,6$ 'sını amiloid grubu oluştururken, bu oran AAA grubunda $\% 33,3$, kontrol grubunda ise $\% 13,8$ idi. Doku dopplerde ise Lateral Em/Am oranı 1'in altında olan hastaların \%5,1'i amiloid grubu oluşturmaktayken, bu oran sırasıyla AAA grubunda $\% 24,2$, kontrol grubunda ise \%10,7 idi. Doku doppler ekokardiyografide mitral kapak bölgesel (Em/Am) incelemede sol ventrikül diyastolik disfonksiyonu sıklığı konvansiyonel ekokardiyografiye göre daha fazla saptanmıştır.

Diyastolik disfonksiyonun geç döneminde erken diyastolik akım velositesinin arttığı, geç diyastolik akım velositesinin ise azaldığı gösterilmiştir ${ }^{17}$. Erken dönemdeki hastaların izlemi sonucu, semptomların artması ile birlikte restriktif örneğin ortaya çıktığı kaydedilmiştir ${ }^{16}$. Klein ve ark. ${ }^{17}$ bu bulgularla uyumlu olarak, restriktif özellikte diyastolik mitral akım örneği olanların yaşam süresinin daha kısa olduğunu göstermişler, kalp transplantasyonu endikasyonları arasında sol ventrikül diyastolik doluş örneğinin de parametre olarak yeralması gerektiğini savunmuşlardır. Çalışmamızda, mitral kapakta hem konvansiyonel hem de doku doppler ekokradiyografik değerlendirmede geç diyastolik akım velositesi sekonder amiloid grubunda daha yüksekti. Bu bulgular relaksasyon bozukluğunun geliştiğini düşündürmektedir. Diyastolik disfonksiyon saptanan hastalarımızda restriktif patern bulgusu izlenmemiştir.

Kardiyak amiloidozlu hastaların standart konvansiyonel ekokardiyografik incelemelerinde ventrikül duvarlarının kalınlaştığı, atriumların dilate, sol ventrikül kavitesinin normal ya da küçük olduğu rapor edilmiştir ${ }^{9}$. Tipik görünüm, miyokard içindeki granüler parıltılardır. Çalışmamızda ise, hem ventrikül duvarlarının kalınlığı, atriumların boyutları, sol ventrikül kavitesinin boyutları ve sol ventrikül kitle indeksi hem de aortaya ait ölçümlerde gruplar arasında anlamlı farklılık saptanmadı.

Yaş ile birlikte intima-media kalınlığı artar ve bu nedenle bir kardiyovasküler risk göstergesi olarak kullanılır. Ölçüm yapan kişiden kaynaklanabilecek hataları en az düzeye indirmek amacıyla tüm ölçümler tek radyolog tarafından yapıldı. Primer amiloidozis olgularında karotis intima-media kalınlığının arttğına dair yayınlar bulunmaktadır. Modesto ve ark.'nın ${ }^{18} 59$ primer amiloidozis hasta grubunda yapmış oladukları çalışmada, karotis intima-media kalınlığının kontrol sağlıklı gruplara göre istatiksel olarak anlamlı derece arttığı gözlenmiştir. AAA hastalarında karotis intimamedia kalınlığının kontrol sağlıklı gruplara göre arttığını gösteren çalışmalar mevcuttur. Uğurlu ve ark. ${ }^{19}$ 100 AAA hastasında karotis intima-media kalınlığının sağlıklı kontrol grubuna göre artmış olduğunu bildirmişlerdir. Sekonder amilodozis olgularında karotis intima-media kalınlığının artıp artmadığını gösteren çalışmalar yeterli değildir. Çalışmamızda ise, AAA hasta grubunun karotis intima-media kalınlığı sağlıklı kontrol grubuna göre istatiksel olarak anlamlı derecede artmış saptandı. Sekonder amiloid gelişen hastaların karotis intima-media kalınlıkları hem AAA hem de sağlıklı kontrol grubundan belirgin olarak daha fazlaydı.

Koroner arter hastalığında aortik elastikiyetin bozulduğu gösterilmiştir ${ }^{20}$. Aortik elastisite özellikleri koroner arter hastalığında prediktif role sahip olmakla birlikte, amilodi gelişmiş hasta gruplarında yapılmış çalışmalar yeterli değildir. Sarı ve ark. ${ }^{9}$ AAA hastaların aortik elastisite özelliklerinin sağlıklı kontrol grubu ile benzer olduğunu göstermişlerdir. Çalışmamızda da amiloid ve AAA hasta grupları ile sağlıklı kontrol grupları arasında aort elastisitesi özelliklerini gösteren parametreler (aortik strain, beta indeks, aortik distensibilite) benzer idi. Aort elastisitesi erken dönemde özellikle non-invaziv metod yöntemiyle ölçülerek kardiyovasküler riski predikte etmede ve önlemede katkı sağlayabilir ${ }^{21}$. Bu konu ile ilgili fazla sayıda prospektif çalışmalara gereksinim duyulmaktadır.

Çalışmamız bazı limitasyonlar içermektedir. Çalışma hastaneye başvuran hastalardan seçildiği için sonuçlar toplum geneline yansıtılamaz. Hastalara ait verilerretrospektif olarak hasta dosya kayıtlarından elde edildiğinden olası biasları en aza indirilmeye çalışıldı. Amiloid grubu, AAA'ya sekonder oldukları aile öyküsü ve klinik özellikleri ile kabul edilerek takip edilmiş ve AAA tanı yaşına ait veriler içermemekteydi. Renal 
amiloidozu gösterilen hastaların renal fonksiyonları ve proteinüri düzeylerine ait verilerbulunmamaktadır.

Bu çalışmadaki bulgular, ailevi Akdeniz ateşine sekonder gelişen amiloid hastalarında relaksasyon bozukluğunun ön planda olup, mitral akım örneğinde erken diyastolik akım velositesinin azaldığı, geç diyastolik akım velositesinin arttığını göstermiştir. Subklinik bir miyokardiyal tutulumun olabileceğini düşündürmektedir. Ayrıca aort ve perikardiyumun bu hastalarda etkilenmediği gözlenmiştir. Ülkemizde sık görülen ailevi Akdeniz ateşine sekonder amiloidozlu olgularda hastalıkla ilişkili olabilecek kardiyovasküler bulguların daha geniş katılımlı prospektif çalışmalarla değerlendirilmesine gereksinim duyulmaktadır.

\section{KAYNAKLAR}

1. Delanaye P, Krzesisnski JM. Massive renal and adrenal calcifications in a young dialysis patients with familial mediterranean fever. Nephrol Dial Transplant. 2005;20:38. https://doi.org/10.1093/ndt/gfh481

2. Mor A, Shinar Y, Zaks N, et al. Evalutionof disease severityin familial mediterranean fever. Semin Arthritis Rheum. 2005;35:57-64.

https://doi.org/10.1016/j.semarthrit.2005.02.002

3. Abdallah E and E Waked. Incidence and clinical outcome of renal amyloidosis: a retrospective study. Saudi J Kidney Dis Transpl. 2013 Sep;24(5):950-8.

https://doi.org/10.4103/1319-2442.118094

4. Güven Y. Amiloidoz gelişmiş ailevi akdeniz ateşi hastalarında adrenal bez rezerv yetmezliğinin gösterilmesi. Uzmanlık Tezi, Haydarpaşa Numune Eğitim ve Araştırma Hastanesi, İç Hastalıkları Kliniği. 2009.

5. Cueto-Garcia L, Reeder GS, Kyle RA, et al. Echocardiographic findings in systemic amyloidosis: spectrum of cardiac involvement and relation to survival. J Am Coll Cardiol. 1985;6:73743. https://doi.org/10.1016/S0735-1097(85)80475-7

6. Ceylan 0 , Özgür S, Orun UA et al. Assessment of left ventricular functions with tissue Doppler, strain and strain rate echocardiography in patients with familial Mediterranean fever. Anatol J Cardiol. 2016 Aug; 15(8):663-8. https://doi.org/10.5152/akd.2014.5544

7. Siquiera-Filha AG, Cunha CLP, Tajik AJ, et al. M-Mode and 2-D echocardiographic features in cardiac amyloidosis. Circulati- on. $1981 ; 63: 188-96$.

https://doi.org/10.1161/01.CIR.63.1.188

8. Devereux RB, Alonsa DR, Lutas EM et al. Echocardiographic assessment of left ventricular hypertrophy: comparison to necropsy findings. Am J Cardiol. 1986 Feb 15;57(6):450-8. https://doi.org/10.1016/0002-9149(86)90771-X

9. Sari I, Arican O, Can G et al. Assessment of aortic stiffness and ventricular functions in familial Mediterranean fever. Anadolu Kardiyol Derg. 2008 Aug;8(4):271-8.

10. Eroğlu S, Yildirir A, Gultekin B ve ark. Kardiyak Amiloidozis. Anadolu Kardiyol Derg. 2006;6:99-100.

11. Nevnihal Eren. Diyastolik Kalp Yetersizliği. Turkiye Klinikleri J Cardiol. 2000;13(2):98-104.

12. Reed B, Villeneuve S, Mack W et al. Associations between serum cholesterol levels and cerebral amyloidosis. JAMA Neurol. 2014 Feb;71(2):195-200. https://doi.org/10.1001/jamaneurol.2013.5390

13. Das M, Mei X, Jayaraman S, Atkinson D, Gursky O. Amyloidogenic mutations in human apolipoprotein A-I are not necessarily destabilizing-a common mechanism of apolipoprotein A-I misfolding in familial amyloidosis and atherosclerosis. FEBS J. 2014 Jun;281(11):2525-42. https://doi.org/10.1111/febs.12809

14. Klein AL, Hatle LK, Taliercio CP, et al. Serial Doppler echocardiographic follw-up of left ventricular diastolic function in cardiac amyloidosis. J Am Coll Cardiol. 1990:16:1135-41. https://doi.org/10.1016/0735-1097(90)90545-Z

15. Mutlu H. Diyastolik Kalp Yetersziliğnde Ekokardiyografi. Kalp Yetersizliği Elektronik Haber Bülteni. 2009;2:2.

16. Cayli M, Usal A, Kanadasi M, Demir M ve Akpinar O. Sol Ventrikül Diyastolik Fonksiyonun Değerlendirilmesinde Yeni Bir Yöntem: Doku Doppler Ekokardiyografi. Türk Kardiyol Dern Arş. 2004;32:618-25.

17. Klein AL, Hatle LK, Burstow DT, et al. Doppler characterization of left ventricular diastolic function in cardiac amyloidosis. J Am Coll Cardiol. 1989;13:1017-26. https://doi.org/10.1016/0735-1097(89)90254-4

18. Modesto KM, Dispenzieri A, Gertz M et al. Vascular abnormalities in primary amyloidosis. European Heart Journal. 28.8 (2007):1019-1024. https://doi.org/10.1093/eurheartj/ehm066

19. Ugurlu S, Seyahi E, Cetinkaya F, Ozbakir F, Balci H, Ozdogan H. Intima-media thickening in patients with familial Mediterranean fever. Rheumatology (Oxford). 2009 Aug;48(8):911-5. https://doi.org/10.1093/rheumatology/kep131

20. Stefanadis C, Dernellis J, Tsiamis E, et al. Aortic stiffness as a risk factor for recurrent acute coronary events in patients with ischaemic heart disease. Eur Heart J. 2000;21:390-6. https://doi.org/10.1053/euhj.1999.1756

21. Özkan S. Subklinik hipotiroidide aort elastisitesinin değerlendirilmesi. Uzmanlık Tezi. Haydarpaşa Numune Eğitim ve Araştırma Hastanesi. 2005. 